\title{
High-Temperature Oxidation of Cr-Coated Resistance Upset Welds Made from E110 Alloy
}

\author{
Dmitrii Sidelev*(D), Sergey Ruchkin and Egor Kashkarov \\ School of Nuclear Science and Engineering, National Research Tomsk Polytechnic University, \\ 634050 Tomsk, Russia; ruchkin.2010.2010@mail.ru (S.R.); egor_kashkarov@mail.ru (E.K.) \\ * Correspondence: sidelevdv@tpu.ru; Tel.: +7-3822-70-17-77 (ext. 2518)
}

Citation: Sidelev, D.; Ruchkin, S.; Kashkarov, E. High-Temperature Oxidation of $\mathrm{Cr}$-Coated Resistance Upset Welds Made from E110 Alloy. Coatings 2021, 11, 577. https:// doi.org/10.3390/coatings11050577

Academic Editor: Alberto Palmero

Received: 26 April 2021

Accepted: 14 May 2021

Published: 15 May 2021

Publisher's Note: MDPI stays neutral with regard to jurisdictional claims in published maps and institutional affiliations.

Copyright: (c) 2021 by the authors. Licensee MDPI, Basel, Switzerland. This article is an open access article distributed under the terms and conditions of the Creative Commons Attribution (CC BY) license (https:// creativecommons.org/licenses/by/ $4.0 /)$.

\begin{abstract}
The resistance upset welds (RUW) made from E110 alloy without and with $\mathrm{Cr}$ coatings were oxidized in air atmosphere at $1100{ }^{\circ} \mathrm{C}$ for 2,10 and $30 \mathrm{~min}$. The cross-section microstructure, elemental composition and hardness were studied before and after oxidation using optical and scanning electron microscopy, and indentations in welding region. The RUW welding does not noticeably change oxidation kinetics of E110 alloy. The most crucial effect has surface non-regularities formed after welding, which prevent uniform coating deposition on full surface of welded cladding tube and end plug. Cr coating deposition can strongly reduce oxidation of welded E110 alloy, while additional post-processing treatment should be applied to improve surface morphology after RUW welding. Several suggestions favorable to development of ATF Zr-based claddings using Cr coating deposition on welded nuclear rods were discussed.
\end{abstract}

Keywords: Zr welds; high-temperature oxidation; nuclear fuel claddings; zirconium-based alloys; magnetron sputtering; chromium coatings

\section{Introduction}

Currently, accident tolerant fuel (ATF) is being developed to improve safety of light or pressurized water reactors [1,2]. The short-term ATF strategy is aimed to improve safety of already produced Zr-based alloy claddings by deposition of protective coatings. A lot of deposition methods such as magnetron sputtering, cold spraying, laser cladding, arc evaporation and various coating materials $(\mathrm{Cr}, \mathrm{FeCrAl}, \mathrm{CrN}$, etc.) are still being studied to develop ATF claddings resistant under conditions simulating normal and accidental operation of nuclear reactors [2-9]. Nevertheless, the last published data showed that $\mathrm{Zr}$ based alloys can be protected by magnetron deposited $\mathrm{Cr}$ coating during high temperature (HT) oxidation for a long-term period [9]. Such an approach seems to be one of the best prospects for short-term development of ATF. The high potential of $\mathrm{Cr}$ coatings can be also confirmed by the participation of industrial/research institutes such as CEA (France), VNIINM (Russia), KIT (Germany) and others [7,9-11] in several full-scale tests of ATF $\mathrm{Zr}$-based claddings with $\mathrm{UO}_{2}$ fuel in nuclear reactors.

A nuclear fuel rod consists of uranium-based fuel placed in Zr cladding tube ( Ø9 $\mathrm{mm}$ and wall thickness $\sim 0.5 \mathrm{~mm}$ ) with two end plugs. Welding is necessarily applied to join end plugs to a cladding tube at both sides to ensure leak tightness of fuel rods. Different welding methods such as electron-beam welding (EBW), laser beam welding (LBW), tungsten inert gas welding (TIG) and resistance upset-butt welding (RUW) can be used. Therefore, the special attention of ATF development should be devoted to estimate oxidation behavior of Zr-based alloy welds especially in the loss of coolant accident conditions (LOCA). Oxidation tests of EBW, LBW, TIG and RUW welds of Zr-based alloys were studied in several works [12-17]. Vandegrift et al. concluded the most protective behavior of EBW welds of $\mathrm{Zr}-1 \mathrm{Nb}$ alloy in comparison with TIG welds and/or made from Zircaloys (Zry-3 and Zry-4) at HT isothermal and transient conditions in both dry and humid air [12]. Laser processing of Zr-based alloys usually reduces their corrosion resistance in autoclave tests [14,16,18]. 
Segregation of $\mathrm{Nb}$, Fe or $\mathrm{Sn}$ at grain boundaries results in secondary phases precipitations such as $\mathrm{Zr}(\mathrm{Fe}, \mathrm{Cr})_{2}$ which affect the oxidation kinetics of $\mathrm{Zr}$-based alloy welds [17,19]. Additional post-processing can be applied to improve homogeneity of weld microstructure and distribution of secondary phases. The heat treatment at $577{ }^{\circ} \mathrm{C}$ for $5 \mathrm{~h}$ in vacuum resulted in good ductility and strength of LBW welds similar to bulk Zr-based alloys [20]. Corrosion resistance of EBW welds can be improved using electron beam thermocycling treatment coupled with annealing at $580^{\circ} \mathrm{C}$ and mechanical treatment/surface etching [21]. Amorphization of LBW welds made from Zry-4 under low dose $\mathrm{Kr}^{+}$irradiation was used to improve their corrosion resistance [22]. Using a distributed heat source had a positive effect on structure and corrosion resistance of EBW welds made of $\mathrm{Zr}-2.5 \% \mathrm{Nb}$ alloy [23]. Despite special post-treatment processing, the welds made from $\mathrm{Zr}$-based alloys demonstrate poor corrosion resistance. Coating deposition was applied to protect welds from $\mathrm{Al}-, \mathrm{Mg}$-based alloys and steels and considered only for relatively low temperatures [24-26]. Zirconia has a non-protective behavior during HT oxidation; therefore, additional approaches are developing to enhance corrosion resistance of welds for application in ATF nuclear fuel materials. Currently, there are no literature or experimental data concerning the oxidation behavior of RUW welds made from $\mathrm{Zr}-\mathrm{Nb}$ alloys under high temperatures $\left(800{ }^{\circ} \mathrm{C}\right.$ and more). The behavior of coated $\mathrm{Zr}-\mathrm{Nb}$ welds under HT oxidation has not yet been studied.

The aim of this study is to determine the role of $\mathrm{Cr}$ coating deposition on oxidation behavior of resistance upset welds made from E110 alloy. The RUW welds were selected as such type of welding is currently used in technological process of nuclear fuel production in Russia (Rosatom, PJSC (NCCP), Novosibirsk, Russia). Therefore, the samples of RUW welds without and with $10 \mu \mathrm{m}$ thick $\mathrm{Cr}$ coatings were prepared and their oxidation behavior was analyzed.

\section{Materials and Methods}

\subsection{Sample Preparation}

The E110 (0.9-1.1 wt.\% Nb, 0.06-0.1 wt.\% O, Zr balance) alloy samples with RUW welds were prepared by PJSC (NCCP), their geometry and outer view are shown in Figure 1. Chromium coatings were deposited onto the welded samples by using the vacuum installation equipped with multi-cathode magnetron sputtering systems. The detailed description of the installation is presented in previous study [27]. Firstly, the samples were rinsed with acetone in an ultrasonic bath and dried by compressed air for 2 $\mathrm{min}$. Then, the samples were fixed to the substrate-holder and placed in vacuum chamber, which was evacuated up to the base pressure of $2 \times 10^{-3} \mathrm{~Pa}$. The special substrateholders were used to deposit $\mathrm{Cr}$ coating on outer surface of the samples (the inner surface remained uncoated). Prior to deposition, the samples were etched by $\mathrm{Ar}^{+}$ions using an ion source with closed electron drift for $20 \mathrm{~min}$. The following etching parameters were used: Ar pressure of $0.15 \mathrm{~Pa}$, accelerated voltage of $2.5 \mathrm{kV}$ and ion current of $40 \mathrm{~mA}$. The multi-cathode magnetron sputtering system with three disk $\mathrm{Cr}(99.95 \%, \varnothing 90 \mathrm{~mm})$ targets was used for deposition. The temperature of the samples was measured and controlled using an Optris CTlaser 3MH1CF4 (Optris GmbH, Berlin, Germany) infrared pyrometer (spectral range-2.3 $\mu \mathrm{m}$ ) during coating deposition. According to our previous results [28], thick and dense $\mathrm{Cr}$ coating can protect $\mathrm{Zr}-\mathrm{Nb}$ alloy from oxidation at high temperatures during a long-term period. Similar results were also shown in the literature $[7,9]$. Thus, the deposition mode of the $\mathrm{Cr}$ coating was selected based on the previous studies of $\mathrm{Cr}$ coating deposition on flat samples made from $\mathrm{Zr}-\mathrm{Nb}$ alloy and its oxidation performance. The deposition parameters are shown in Table 1. Two types of the coated samples were obtained. The first type of the samples had a $\mathrm{Cr}$ coating on full outer surface, while the second type-Only on a cladding surface (end plug and RUW weld were uncoated). The appearance of the samples is shown in Figure 1. 


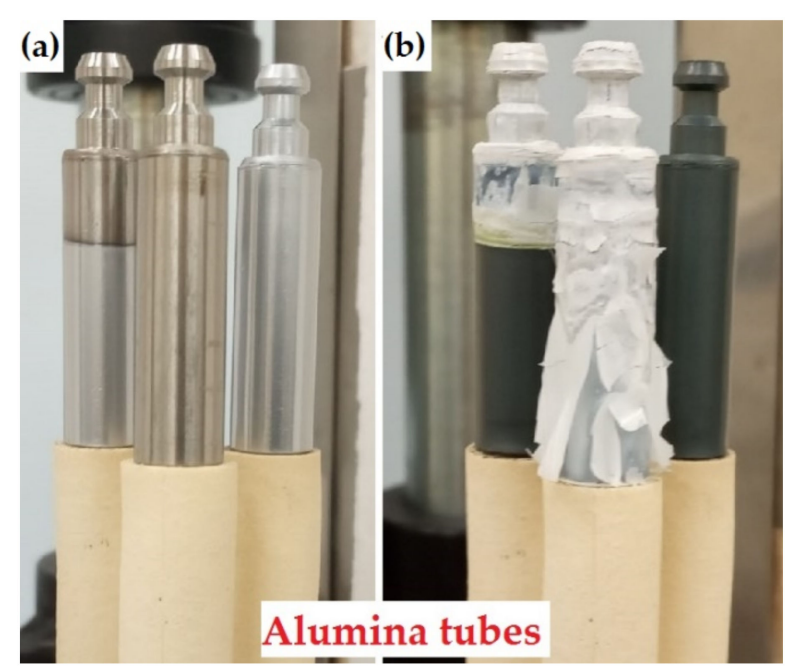

Figure 1. The photographs of the samples (a) before and (b) after oxidation at $1100{ }^{\circ} \mathrm{C}$ for 2 min: left sample-partially Cr-coated; central sample—uncoated; right sample—fully Cr-coated.

Table 1. Deposition mode.

\begin{tabular}{|c|c|c|c|c|c|c|}
\hline$Q, W / \mathrm{cm}^{2}$ & $P, \mathrm{~Pa}$ & $t, \min$ & $U_{\mathrm{sub}}, \mathrm{V}$ & $\begin{array}{c}j_{\mathrm{sub}}, \\
\mathrm{mA} / \mathrm{cm}^{2}\end{array}$ & $T_{\text {sub }},{ }^{\circ} \mathrm{C}$ & $h, \mu \mathrm{m}$ \\
\hline 39.1 & 0.25 & 192 & -100 & 20 & $<390$ & $9.8 \pm 0.4$ \\
\hline
\end{tabular}

\subsection{Oxidation Test}

An atmospheric furnace ATS 3210 (Applied Test Systems Inc., Butler, PA, USA) was used to perform $\mathrm{HT}$ oxidation tests at $1100{ }^{\circ} \mathrm{C}$ for different isothermal periods. The furnace was pre-heated up to $500^{\circ} \mathrm{C}$ and the samples were loaded in the chamber. The alumina tube holders were used. The samples were heated up to $1100{ }^{\circ} \mathrm{C}$ with the rate of $\sim 21^{\circ} \mathrm{C} / \mathrm{min}$ and then were oxidized for 2,10 and $30 \mathrm{~min}$. After HT oxidation, the chamber was opened and the samples were naturally cooled to room temperature $\left(\sim 22^{\circ} \mathrm{C} / \mathrm{min}\right)$. The appearance of the samples in the furnace before and after oxidation is shown in Figure 1. The samples were necessarily photographed before and after each oxidation test.

\subsection{Sample Characterization}

The mass gain of the samples was measured using an analytical balance machine Sartorius CP124S (Goettingen, Germany) with an accuracy of $10^{-4} \mathrm{~g}$. The thickness of the as-deposited $\mathrm{Cr}$ coating and elemental composition of the samples after oxidation were analyzed using scanning electron microscopy (SEM) with energy-dispersive $\mathrm{X}$-ray spectroscopy (EDS) detector (LEO EVO 50, Zeiss, Oberkochen, Germany). To control thickness of as-deposited $\mathrm{Cr}$ coatings and their microstructure, polished $\mathrm{Si}$ (110) substrate was also used in the deposition experiment. Figure 2 shows the cross-section of $\mathrm{Cr}$ coating deposited on $\mathrm{Si}$ substrate. The $\mathrm{Cr}$ coating had dense and columnar microstructure. The thickness of the coating was uniform and equal to $9.8 \pm 0.4 \mu \mathrm{m}$.

The microstructure of the as-received and oxidized samples were studied by an optical microscopy using AXIOVERT 200MAT (Zeiss, Göttingen, Germany). Hardness was measured on the cross-section of the samples with a load of $0.5 \mathrm{~N}$ using Vickers micro-hardness tester Pruftechnik KB-30S (Hochdorf-Assenheim, Germany). The Vickers pyramid from diamond was used as the indenter. The hardness measurements were performed in a welding region before and after the oxidation tests. The distance between indentations was equal to $\sim 100 \mu \mathrm{m}$ (it was higher than $3 d$, where $d$-averaged length of 
diagonals). The dwell time was $15 \mathrm{~s}$. In total, 36 indentations were done for each sample, and the distribution of hardness in a welding region was plotted.

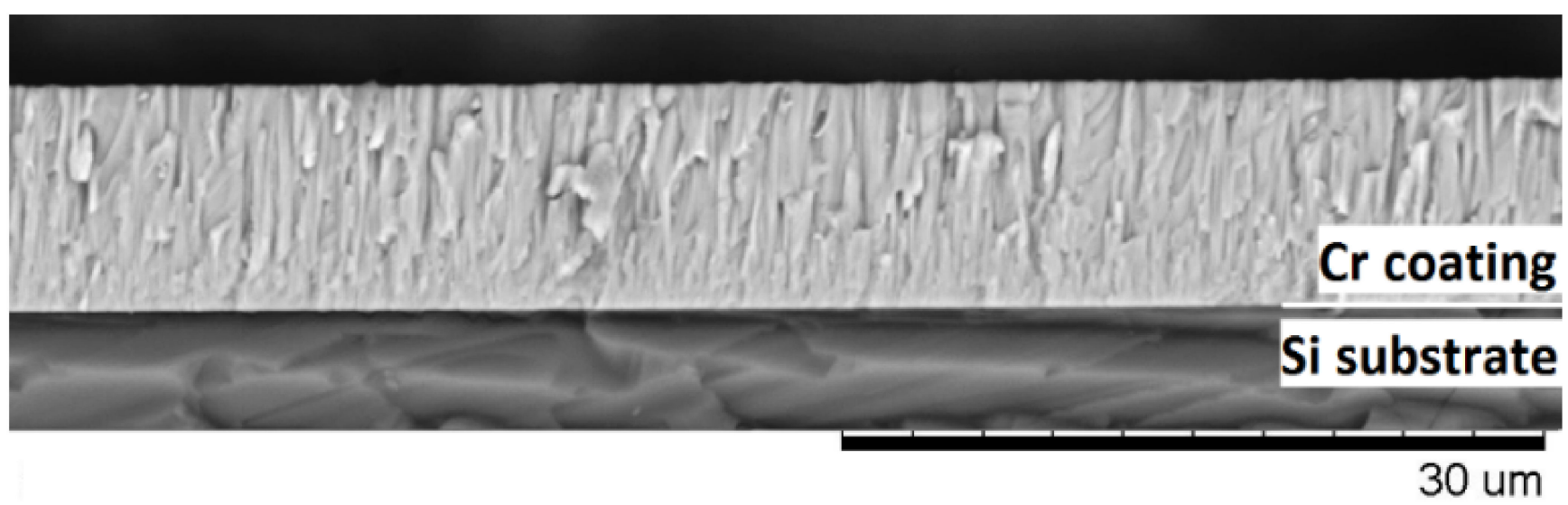

Figure 2. The cross-section of the as-deposited Cr coating on Si substrate.

\section{Results}

\subsection{As-Received Samples}

Figure 3 presents the SEM images of the cross-section of the as-received RUW weld made from E110 alloy.
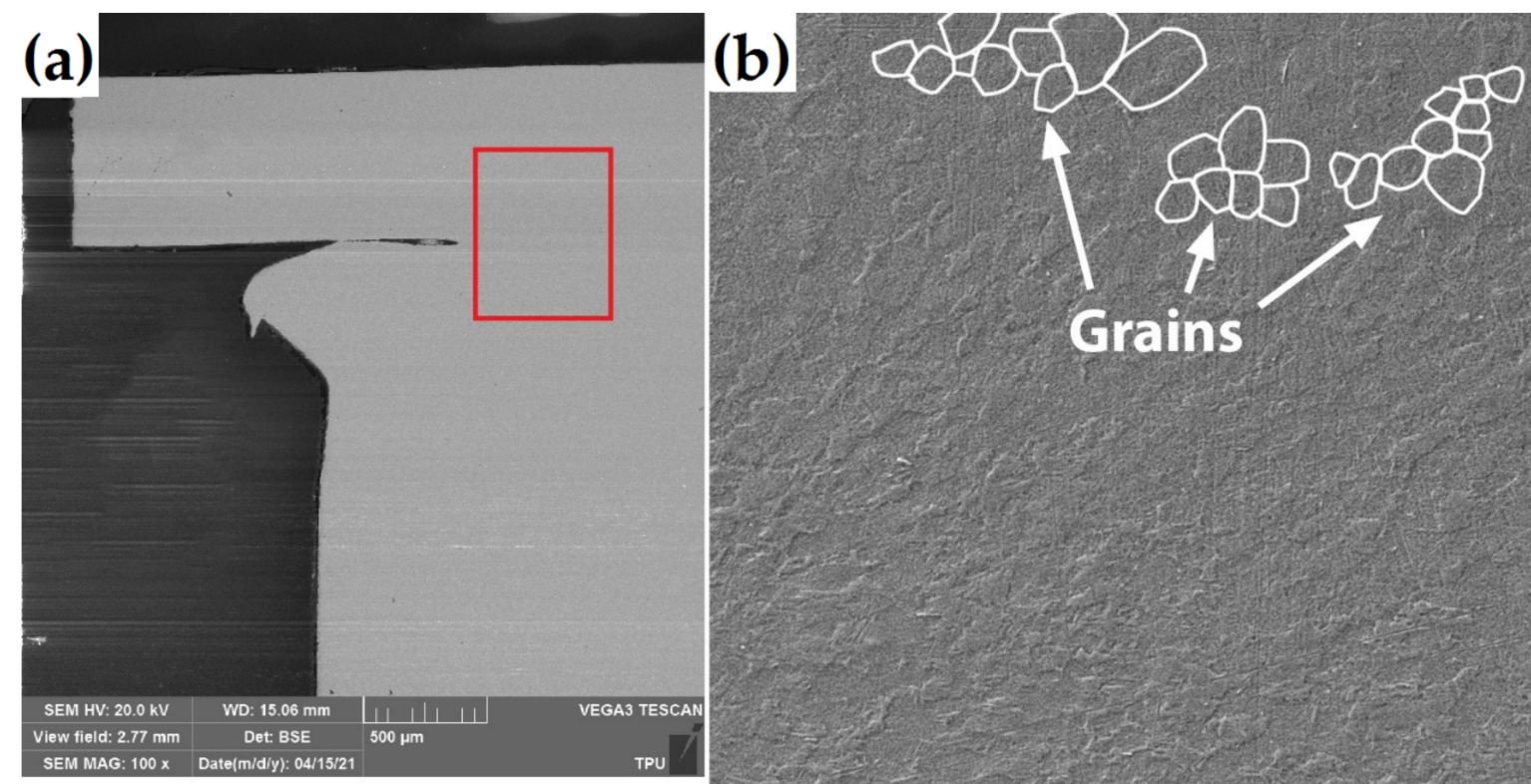

(c)
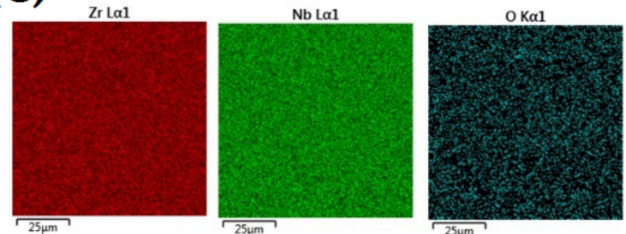

Grains

Figure 3. (a) The SEM images of the cross-section of the as-received RUW weld. The red square indicates measurement position at (b) higher resolution. (c) The EDS-maps of $\mathrm{Zr}, \mathrm{Nb}$ and $\mathrm{O}$ in the welding region.

There was no difference in microstructure of welding region and end plug or cladding tube. The microstructure of the weld region consists of non-equiaxed coarse grains with 
the average size of $\sim 10-12 \mu \mathrm{m}$. The elemental analysis by EDS technique showed uniform distribution of $\mathrm{Zr}$ and $\mathrm{Nb}$ over welding region without any $\mathrm{Nb}$ precipitations. Similar microstructure behavior of $\mathrm{Zr}-\mathrm{Nb}$ and $\mathrm{Zr}$-Sn alloys were also found after EBW welding in [29]. Most likely that the temperature during welding process was enough for dissolution any precipitates in zirconium matrix.

\subsection{Weight Gain Measurements}

Table 2 shows the outer view of the samples after oxidation. White-colored film was grown on the surface of the uncoated sample after oxidation indicating the formation of zirconia scale. The coated sample had dark-green color that is usually observed for chromia scale. The sample with partially $\mathrm{Cr}$ coating had a sharp border of zirconia and chromia that corresponds to the initial position of uncoated and Cr-coated surfaces. Moreover, local oxidation (white-colored area) was found in a burr of RUW welds for the fully Cr-coated samples. These regions are additionally highlighted by red arrows in Table 2 for each sample (after 2, 10, and 30 min oxidation). The samples had similar outer view after 10 min oxidation, but swelling of all samples in bottom part (in region of cladding tube) was found. This effect was caused by oxidation of the inner uncoated area of the tube. The changes of sample geometry were observed in other studies [4], where an inner surface of the tubes was uncoated. The severe degradation of the uncoated sample was found after 30 min oxidation test. The failure of this sample in bottom part was due to its geometry where a thin wall of a cladding tube rapid oxidized on a three sides (outer, internal and face surfaces). At the same time, swelling of the $\mathrm{Cr}$-coated samples in bottom became more pronounced.

Table 2. The outer view of the samples after oxidation.

\begin{tabular}{|c|c|c|c|}
\hline Title & Uncoated & Partially Cr-Coated & Fully Cr-Coated \\
\hline 2 min oxidation & & & \\
\hline 10 min oxidation & & & \\
\hline 30 min oxidation & & & \\
\hline
\end{tabular}

Due to complex geometry of the samples, mass gain after oxidation was calculated and compared only to the uncoated and fully $\mathrm{Cr}$-coated samples to estimate protective properties of $\mathrm{Cr}$ coating (Figure 4) using the next equation:

$$
\text { Mass gain }=\frac{m_{1100}-m_{0}}{m_{0}} \times 100 \%
$$

where $m_{1100}$ - mass of the sample after oxidation at $1100^{\circ} \mathrm{C}, m_{0}$-initial mass of the sample.

Figure 4 shows higher mass gain of the uncoated samples than for the Cr-coated samples. Moreover, the mass gain increased with the change of oxidation time from 2 to $30 \mathrm{~min}$. However, the $\mathrm{Cr}$-coated sample had lower mass gain after $30 \mathrm{~min}$ oxidation (2.0\%) than that after $10 \mathrm{~min}(2.3 \%)$. Such result can be caused by spalling of zirconia from the inner surface of this sample during oxidation test. In common, the obtained results present the decrease in oxidation rate of Cr-coated samples by 2.5-5.0 times in comparison with the uncoated ones for the considered oxidation conditions. The significant decrease in 
mass gain of Cr-coated Zr-based alloys under HT oxidation was found in other studies: in 9 times in air at $1100{ }^{\circ} \mathrm{C}$ for $20 \mathrm{~min}$ [27], in 8-11 times in a steam at $1100{ }^{\circ} \mathrm{C}$ for $850 \mathrm{~s}$ [7], in 2-4 times in a steam at $1200{ }^{\circ} \mathrm{C}$ for $1500 \mathrm{~s}$ [9].

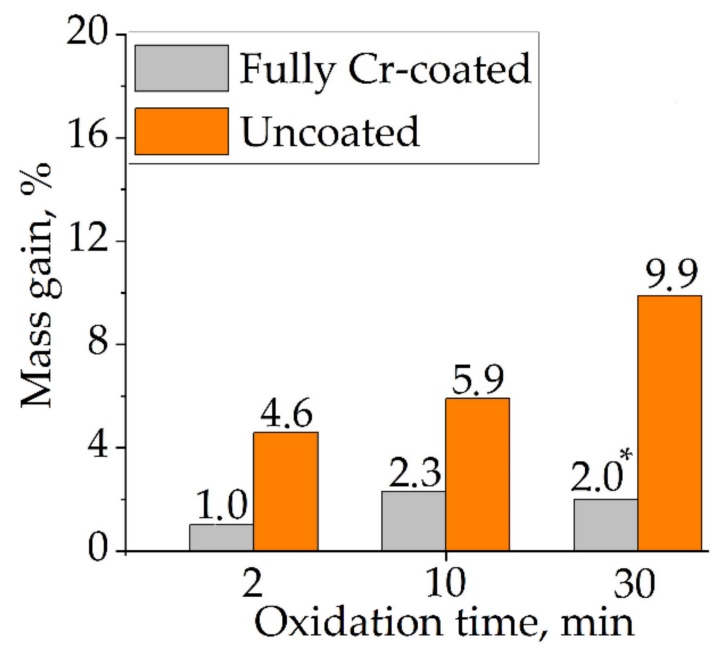

Figure 4. Mass gain of uncoated samples and with full $\mathrm{Cr}$ coating after oxidation at $1100{ }^{\circ} \mathrm{C}$ for 2,10 and $\left.30 \mathrm{~min} .{ }^{*}\right)$ Spalling of zirconia from the inner surface of this sample.

\subsection{Cross-Section Microstructure of the Samples}

Figures 5 and 6 show cross-section microstructures of the uncoated and fully $\mathrm{Cr}$-coated samples after oxidation at $1100^{\circ} \mathrm{C}$. The uncoated sample was predominantly oxidized on its outer surface, while lower oxidation was observed on the internal surface. The most pronounced and crucial oxidation was found in a weld burr region (up to $800 \mu \mathrm{m}$ ) and end plug ( 1 mm). The thickness of oxide layers was less $(50-500 \mu \mathrm{m})$ in other regions.
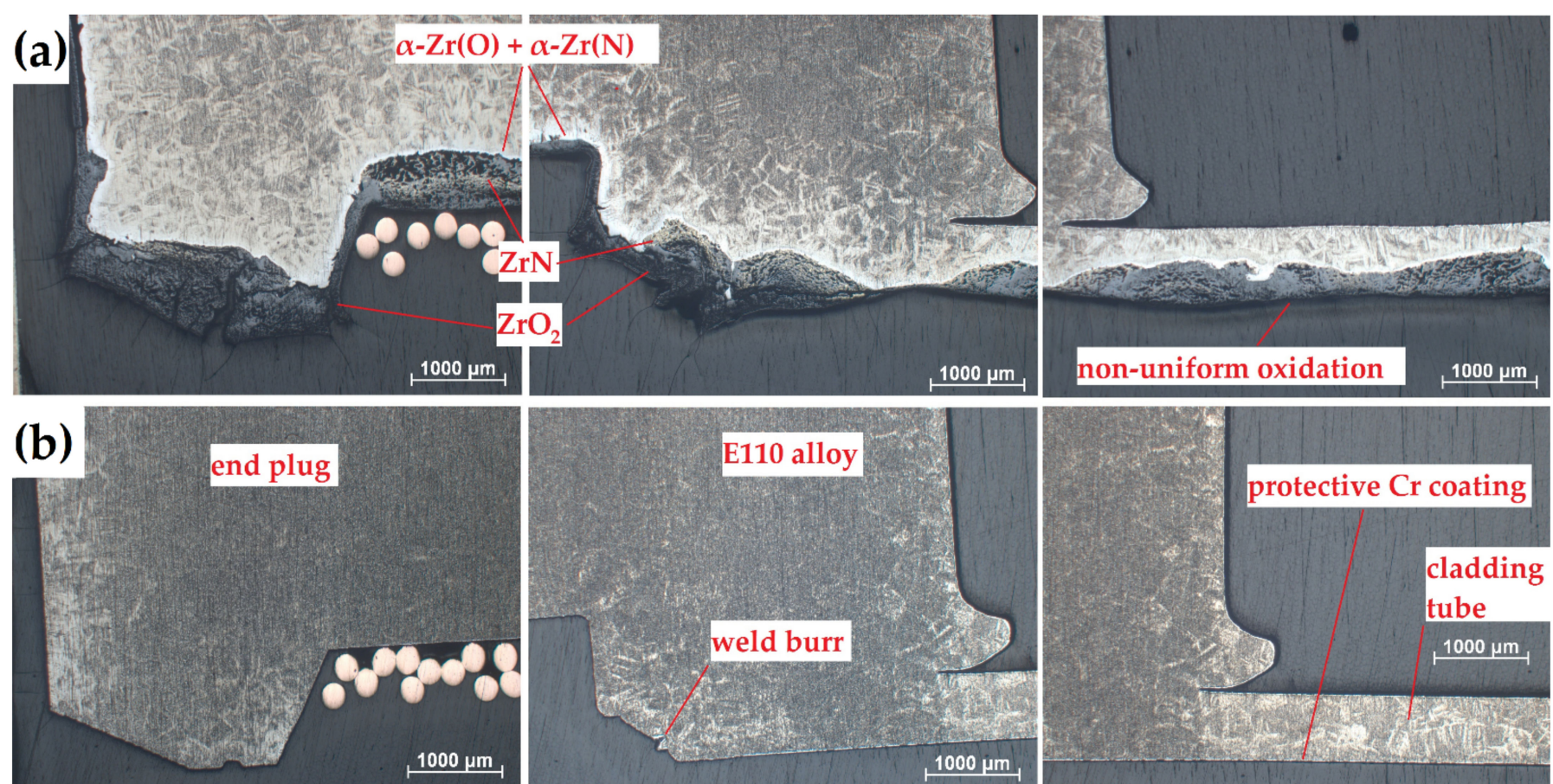

Figure 5. Optical images of cross-section microstructures of (a) uncoated and (b) Cr-coated samples after oxidation at $1100{ }^{\circ} \mathrm{C}$ for $30 \mathrm{~min}$. 

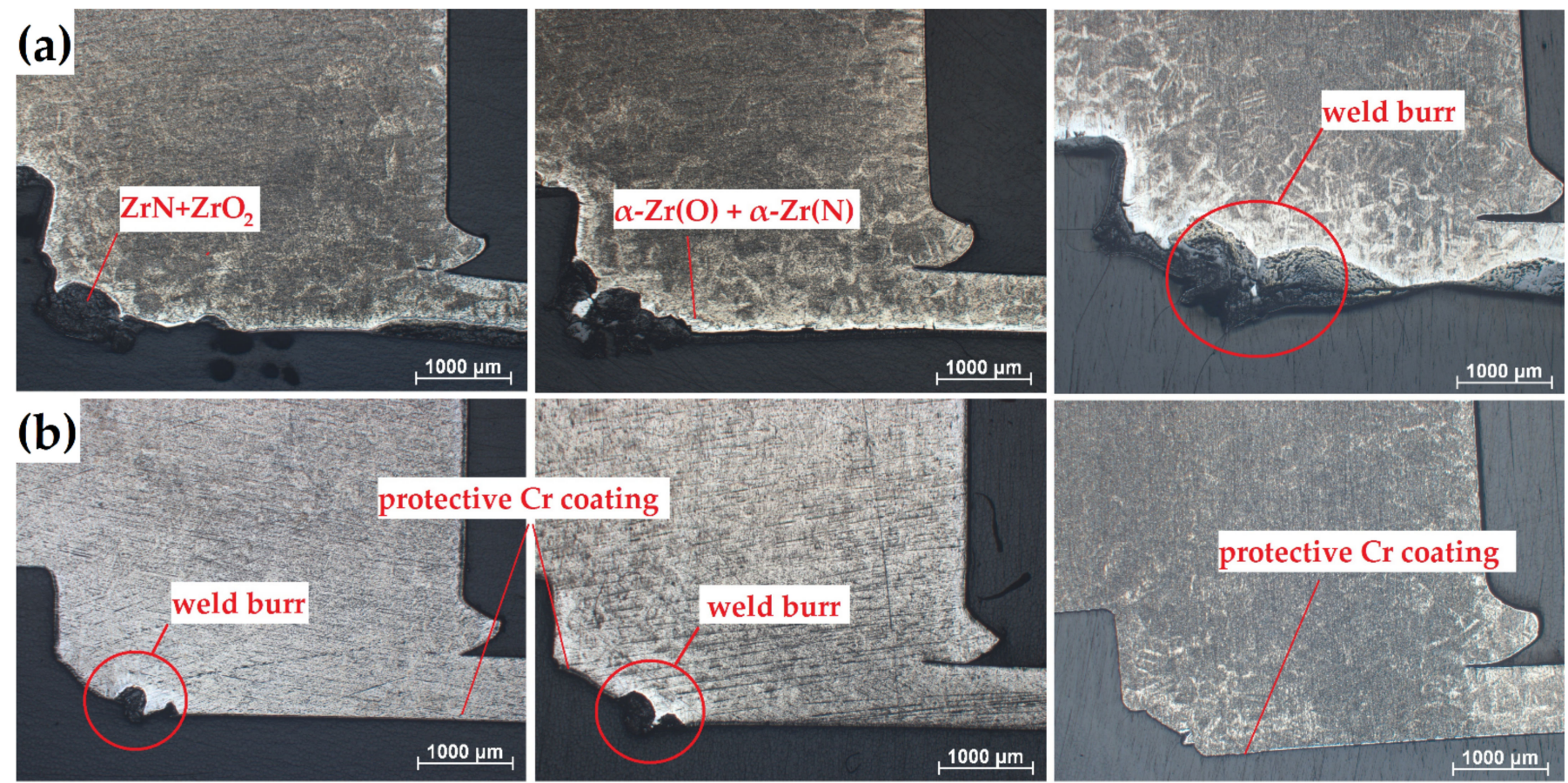

\section{$2 \mathrm{~min}$}

$10 \mathrm{~min}$

\section{$30 \mathrm{~min}$}

Figure 6. Optical photographs of cross-section microstructures of the (a) uncoated and (b) Cr-coated samples in the region of RUW welds after oxidation at $1100{ }^{\circ} \mathrm{C}$ for 2,10 and $30 \mathrm{~min}$.

According to Figure 6, high oxidation was observed in a weld burr region of the uncoated samples. The thickness of oxide layers increased from 300 to $800 \mu \mathrm{m}$ as the oxidation time was changed from 2 to $30 \mathrm{~min}$. The high non-uniformity of the oxide layer formed on the uncoated sample can be additionally caused by "nitrogen effect" [30,31]. The latter strongly accelerates oxidation kinetics of $\mathrm{Zr}$-based alloys due to $\mathrm{ZrN} \rightarrow \mathrm{ZrO}_{2}$ transformation accompanied by high volume expansion $(\sim 48 \%)$. The accelerated degradation of Zircalloy-4 and M5 alloys in air were also found in [31], where the significant role on oxidation rate and non-uniformity was belonged to re-oxidation process of $\mathrm{ZrN}$ to $\mathrm{ZrO}_{2}$. This was usually pronounced at temperatures higher than $800{ }^{\circ} \mathrm{C}$.

In the case of fully $\mathrm{Cr}$-coated samples, outer surface of the samples had protective chromia scale under the considered oxidation conditions excluding the region of weld burr. This effect was clearly seen in the appearance of the samples after oxidation tests (Table 2). For both types of the samples, the formation of different surface morphology in a weld burr region during welding should be taken into account, when performing the comparative analysis. Thus, it also can influence the oxidation behavior (see Figure $6 \mathrm{~b}$ ).

The $\mathrm{ZrN}$ and $\mathrm{ZrO}_{2}$ grains were clearly seen in the uncoated regions of the samples at higher optical resolution (Figure 7). While the fully $\mathrm{Cr}$-coated sample had the multilayered structure of $\mathrm{Cr}_{2} \mathrm{O}_{3}$ oxide layer/residual $\mathrm{Cr}$ layer/Cr-Zr interdiffusion layer/E110 alloy which is typically observed in oxidized $\mathrm{Cr}$-coated $\mathrm{Zr}$-based alloys during protective scale (Figure 7c) $[9,28]$. The cross-section microstructure of the partial Cr-coated sample is presented in Figure $7 \mathrm{~b}$. The $\mathrm{Cr}$ coating was still adherent at the border of coated/uncoated regions of the sample even at $1100{ }^{\circ} \mathrm{C}$ up to $30 \mathrm{~min}$. Moreover, oxide layer was predominantly grown in the depth, while less kinetics was observed in the side direction (underneath the $\mathrm{Cr}$ coating). It indicates high coating adhesion of $\mathrm{Cr}$ to $\mathrm{Zr}$-based alloys, which is typical for magnetron sputtering technologies and in the case of using special pre-treatment procedures like ion cleaning, preliminary heating, etc. [32,33]. 


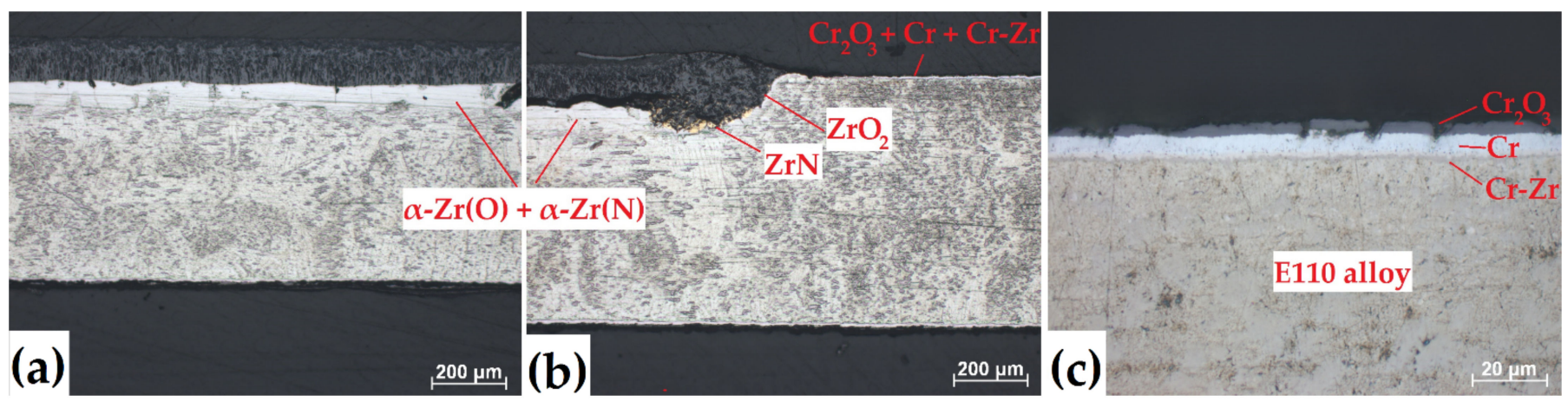

Figure 7. Optical images of cross-section microstructures of the (a) uncoated, (b) partially and (c) fully Cr-coated samples in the region of cladding tube after oxidation at $1100{ }^{\circ} \mathrm{C}$ for $30 \mathrm{~min}$.

\subsection{Elemental Composition of the Samples}

Figure 8 shows elemental compositions over depth of the uncoated and $\mathrm{Cr}$-coated samples after $30 \mathrm{~min}$ oxidation at $1100{ }^{\circ} \mathrm{C}$. According to EDS line-scans, the uncoated sample was strongly oxidized. A lot of microcracks were found on its surface. The $\mathrm{O}$ and $\mathrm{N}$ signals were found at the depth of $500 \mu \mathrm{m}$ and more in E110 alloy. At the same time, the penetration depth of oxygen and nitrogen was less $\sim 5 \mu \mathrm{m}$ in the case of the Cr-coated samples. It corresponds to one half of the thickness of the as-deposited $\mathrm{Cr}$ coatings. No sign of $\mathrm{O}$ or $\mathrm{N}$ were found in the E110 alloy, when the fully Cr-coated sample was studied. However, a thin $(1.5-2.5 \mu \mathrm{m})$ diffusion layer of $\mathrm{Cr}$ and $\mathrm{Zr}$ was detected underneath the residual Cr layer.

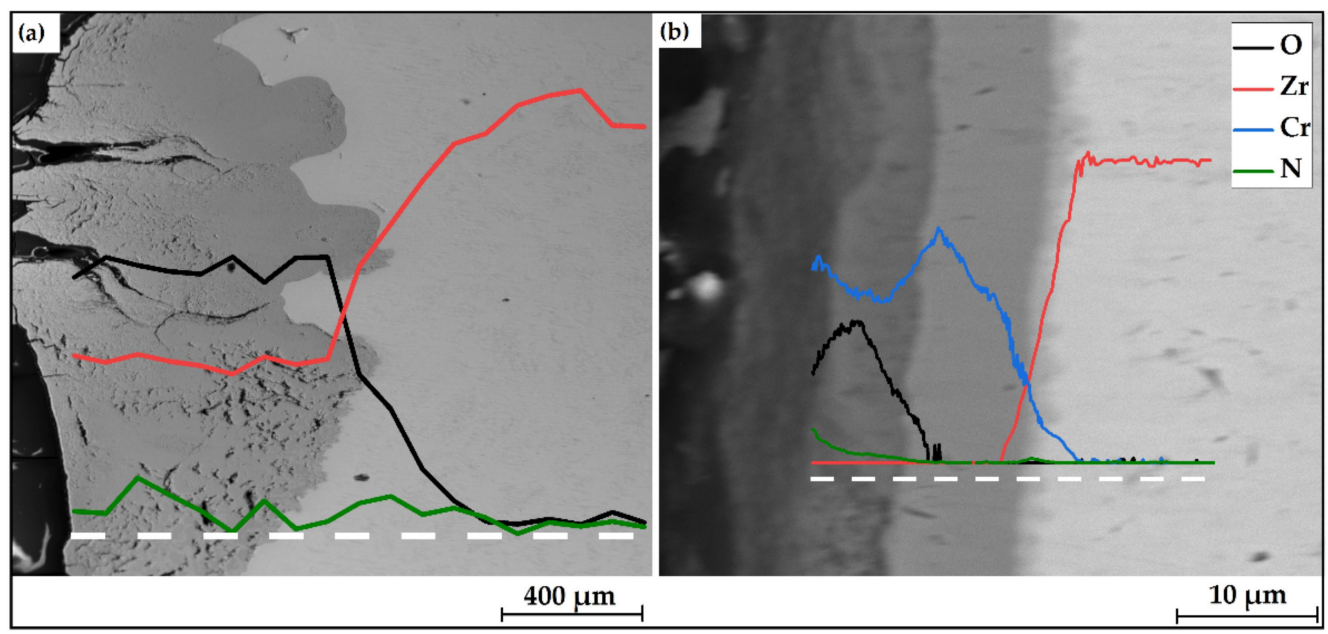

Figure 8. EDS-line scans of the (a) uncoated and (b) Cr-coated samples after 30 min oxidation at $1100{ }^{\circ} \mathrm{C}$. White dashed lines indicate the measurement position.

\subsection{Hardness Distributions}

Figure 9 shows hardness maps of the cross-section of the RUW welds made from E110 alloy before and after oxidation at $1100{ }^{\circ} \mathrm{C}$ for 2, 10 and $30 \mathrm{~min}$. The hardness of the as-received sample in the welding region was uniform and equal to $185-215 \mathrm{HV}$, which corresponds to the value for bulk $\mathrm{Zr}-\mathrm{Nb}$ alloys [34]. The increase in hardness up to 300 , 350 and $420 \mathrm{HV}$ was found for the uncoated samples after 2, 10 and $30 \mathrm{~min}$ oxidation, respectively. The oxygen and nitrogen diffusion results in the increase in hardness of $\mathrm{Zr}$ based alloy due to the formation of $\alpha-\operatorname{Zr}(\mathrm{O})$ or $\alpha-\operatorname{Zr}(\mathrm{N})$ phases under HT oxidation [35]. The hardness maps for $\mathrm{Cr}$-coated welds demonstrate high protective properties of the coating. The average hardness values in the weld region are slightly decreased to $145-190 \mathrm{HV}$ after oxidation that can be caused by thermal treatment (grain growth). 

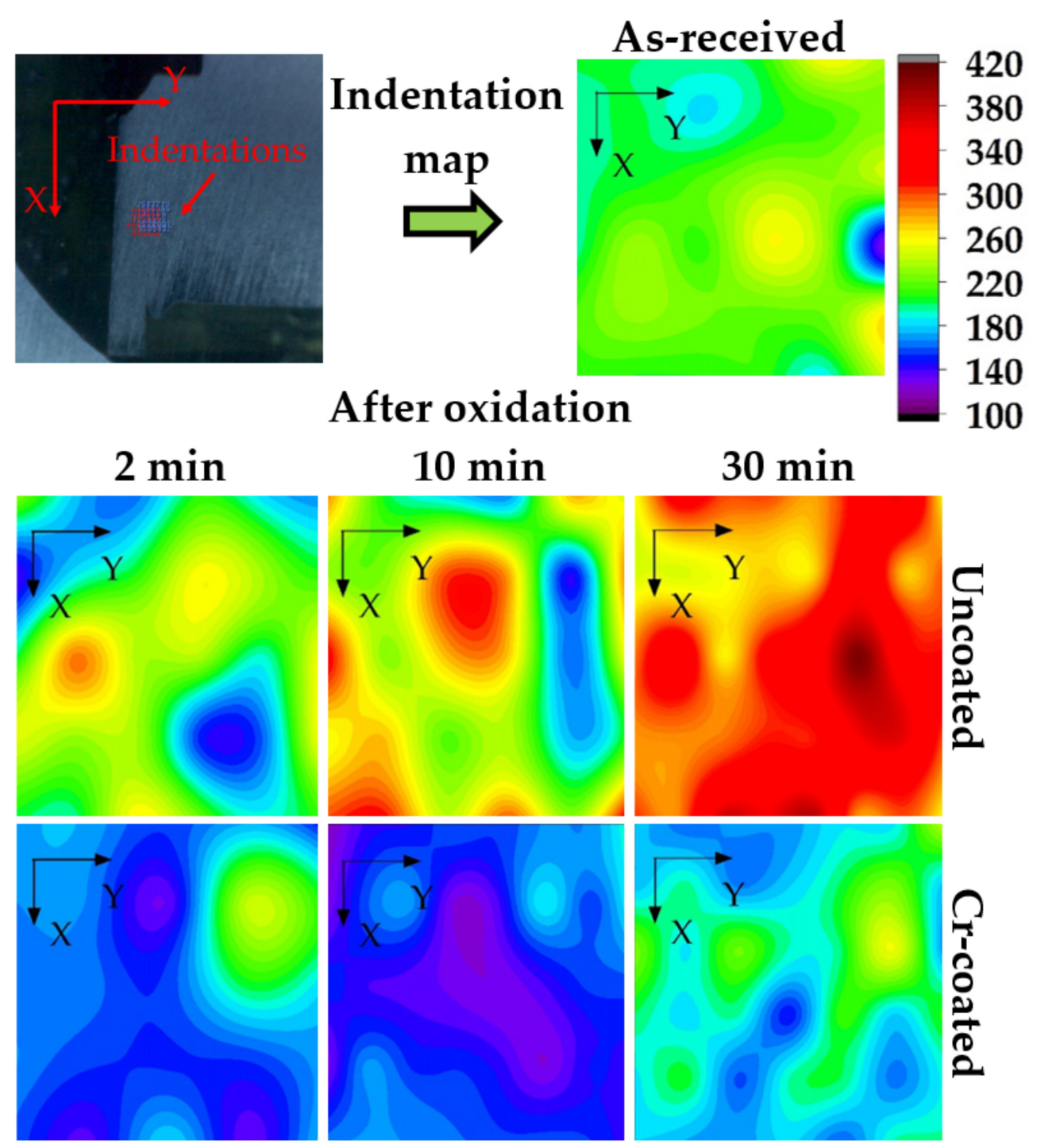

Figure 9. Hardness map (in HV) of the cross-section of RUW welds before and after oxidation at $1100{ }^{\circ} \mathrm{C}$.

\section{Discussion}

The oxidation behavior of the uncoated and Cr-coated RUW welds made from E110 alloy was studied. Oxidation tests were performed in air atmosphere at $1100{ }^{\circ} \mathrm{C}$ for 2,10 and $30 \mathrm{~min}$. The uncoated samples were strongly oxidized due to non-protective scale of zirconia at high temperatures. The presence of $\mathrm{N}$ in atmosphere accelerated oxidation rate of the samples and resulted in the non-uniform growth of oxide layer over the cross-section of the samples. Cracking and spallation of zirconia layers can cause breakaway oxidation of Zr-based alloys that was also found in other studies during high-temperature (800$1200{ }^{\circ} \mathrm{C}$ ) oxidation, especially in nitrogen-content atmosphere $[27,31,36]$. Nevertheless, the comparison of oxide thickness in welding zone, end plug and cladding tube showed the predominantly oxidation in the region of weld burr.

The geometry of the samples can also have influence on oxidation rate in different regions of the uncoated samples. Zirconium oxidation is an exothermic reaction $\left(\Delta H=-584.5 \mathrm{~kJ} / \mathrm{mol}\right.$ at $\left.1200^{\circ} \mathrm{C}\right)$ [27] that can result in non-uniform heating of the samples during HT oxidation. Taking into account the equal (or similar) surface area of cladding tube and end plug, a thin-wall cladding tube can be heated up to higher temperatures than end plug having higher volume. This effect can also influence on oxidation kinetics of the investigated samples that was clearly observed in their appearance (Table 2). 
The deposition of $10 \mu$ m-thick $\mathrm{Cr}$ coatings effectively prevented the oxidation of welded E110 alloy under the considered conditions. The formation of protective scale of chromia with the thickness of $\sim 5 \mu \mathrm{m}$ and $\mathrm{Cr}-\mathrm{Zr}$ diffusion layer at the "Cr coating-E110 alloy" interface were found after the oxidation test at $1100{ }^{\circ} \mathrm{C}$ for $30 \mathrm{~min}$. According to EDS line-scans and hardness maps (Figures 8 and 9), oxygen and nitrogen can diffuse to the welding region with the formation of hard and brittle solid solutions of $\alpha-\operatorname{Zr}(\mathrm{O})$ and $\alpha-\mathrm{Zr}(\mathrm{N})$. Therefore, the double increase (up to $420 \mathrm{HV}$ ) of hardness was found in the region of RUW weld for the uncoated samples after $30 \mathrm{~min}$ HT oxidation. The abovementioned results showed enough coating thickness $(10 \mu \mathrm{m})$ of $\mathrm{Cr}$ to protect the welded E110 alloy under $30 \mathrm{~min}$ oxidation at $1100{ }^{\circ} \mathrm{C}$. Such or some higher coating thickness $(10-15 \mu \mathrm{m})$ was also suggested as an optimum for steam oxidation at $1100-1200{ }^{\circ} \mathrm{C}$ by other authors [7,9]. Nevertheless, the Cr-Zr interdiffusion can be a problem of coated nuclear rods at HT oxidation conditions, so a coating thickness can be increased. The protective coating can be consumed by diffusion and dissolution of $\mathrm{Cr}$ in $\mathrm{Zr}$-based alloys at high temperatures [10]. Moreover, the melting temperature of liquid eutectic $\mathrm{Cr}_{2} \mathrm{Zr}$ phase is in the range of $1305-1332{ }^{\circ} \mathrm{C}$ [9,37-39], so surface of $\mathrm{Cr}$-coated cladding can melt that results in loss of protectiveness and cause oxidation of zirconium. Thus, a barrier sublayer (e.g., Mo, Ta, etc.) should be additionally applied for prevention of $\mathrm{Cr}-\mathrm{Zr}$ interdiffusion at temperatures higher $1300{ }^{\circ} \mathrm{C}[39,40]$.

Despite high protectiveness of the Cr coatings presented in Section 3.3, the local oxidation can occur in the region of weld burr (Figure 10). Thus, the additional posttreatment of the RUW welds should be needed to decrease surface roughness of weld burr and uniform coating deposition. For this purpose, mechanical processing, chemical etching [21] or ion-plasma treatment [41] can be considered.

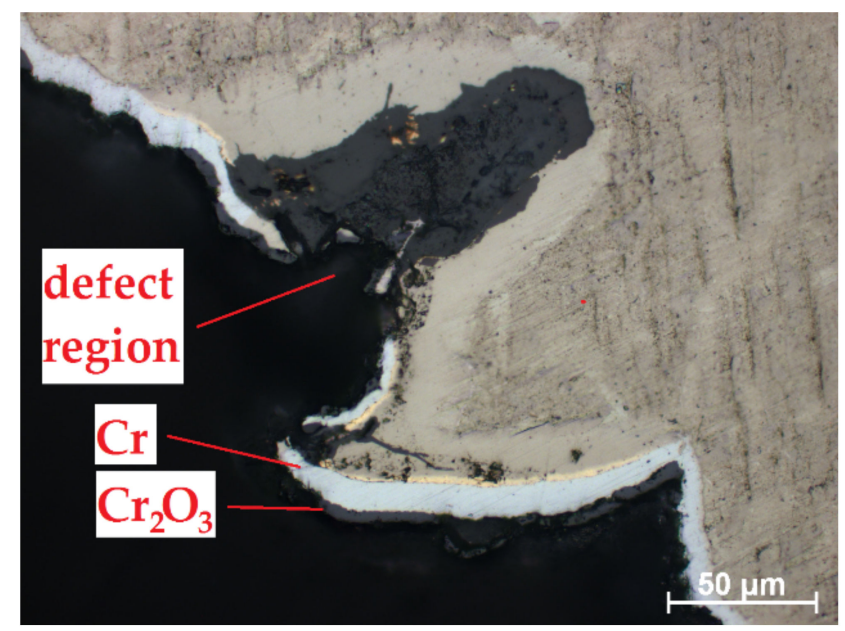

Figure 10. Oxidation of Cr-coated RUW weld in a weld burr region.

It should be noted that lower oxidation kinetics of E110 alloy in the border of uncoated and $\mathrm{Cr}$-coated regions also like as lower oxide thickness in the defect region of weld burr in the case of the fully $\mathrm{Cr}$-coated samples. The oxide layer predominantly formed into the depth of E110 alloy than in side direction (under the protective coating). However, the deposition of $\mathrm{Cr}$ coating onto full surface of the samples seems to be better than partially coating deposition (only on cladding tube). The obtained results can be used for development of coating technology for ATF Zr-based claddings.

\section{Conclusions}

The oxidation behavior of RUW-welded samples made from E110 alloy with and without $\mathrm{Cr}$ coatings was investigated. The comparative analysis of their cross-section microstructures, elemental distributions over a depth, hardness before and after oxidation in air at $1100{ }^{\circ} \mathrm{C}$ revealed the following conclusions. 
1. The RUW welding of E110 alloy does not change oxidation kinetics at high temperatures. The surface non-regularities in the region of weld burr have the most pronounced effect on oxidation rate.

2. The Cr coatings can protect RUW-welded samples from oxidation at high temperatures. Partial coating deposition on $\mathrm{Zr}$ claddings, especially in the case of uncoated weld, leads to uneven oxidation and material degradation in the area of the end $\mathrm{plug} / \mathrm{Zr}$ cladding tube. Therefore, the coating deposition on the full surface of nuclear fuel rods after welding of end plugs and cladding seems to be advantageous for development of ATF Zr-based claddings.

3. Additional post-treatment procedures like mechanical processing, chemical etching or ion-plasma treatment should be considered for surface smoothing of nuclear fuel rod after RUW welding.

Author Contributions: Conceptualization, D.S.; validation, E.K.; formal analysis, D.S. and E.K.; investigation, D.S., E.K. and S.R.; resources, D.S. and E.K.; data curation, S.R.; writing-original draft preparation, D.S.; writing—review and editing, E.K.; visualization, S.R.; supervision, D.S.; project administration, D.S. and E.K.; funding acquisition, D.S. and E.K. All authors have read and agreed to the published version of the manuscript.

Funding: The reported study was supported by the Russian Science Foundation, Grant No. 19-7910116.

Institutional Review Board Statement: Not applicable.

Informed Consent Statement: Not applicable.

Data Availability Statement: Data is contained within the article.

Acknowledgments: The authors are grateful to Sergey Buymov and Petr Yurin (PJSC "NCCP") for the sample preparation by resistance upset welding. The authors thank Maksim. Krinitcyn (Institute of Strength Physics and Materials Science SB RAS) for the optical measurements. The authors are grateful to Tomsk Polytechnic University Enhancement Program.

Conflicts of Interest: The authors declare no conflict of interest.

\section{References}

1. Goldner, F. Development Strategy for advanced LWR Fuels with Enhanced Accident Tolerance; USDOE Office of Nuclear Energy: Washington, DC, USA, 2012.

2. Tang, C.; Stueber, M.; Seifert, H.J.; Steinbrueck, M. Protective coatings on zirconium-based alloys as accident-tolerant fuel (ATF) claddings. Corros. Rev. 2017, 35, 141-165. [CrossRef]

3. Kim, H.-G.; Kim, I.-H.; Jung, Y.-I.; Park, D.-J.; Park, J.-Y.; Koo, Y.-H. Adhesion property and high-temperature oxidation behavior of Cr-coated Zircaloy-4 cladding tube prepared by 3D laser coating. J. Nucl. Mater. 2015, 465, 531-539. [CrossRef]

4. Kuprin, A.S.; Belous, V.A.; Voyevodin, V.N.; Bryk, V.V.; Vasilenko, R.L.; Ovcharenko, V.D. Vacuum-arc chromium-based coatings for protection of zirconium alloys from the high-temperature oxidation in air. J. Nucl. Mater. 2015, 465, 400-406. [CrossRef]

5. Park, J.H.; Kim, H.-G.; Park, J.; Jung, Y.-I.; Park, D.-J.; Koo, Y.-H. High temperature steam-oxidation behavior of arc ion plated Cr coatings for accident tolerant fuel claddings. Surf. Coat. Technol. 2015, 280, 256-259. [CrossRef]

6. Sevecek, M.; Gurgen, A.; Seshadri, A.; Che, Y.; Wagih, M.; Phillips, B.; Champagne, V.; Shirvan, K. Development of Cr cold spray-coated fuel cladding with enhanced accident tolerance. Nucl. Eng. Technol. 2018, 50, 229-236. [CrossRef]

7. Brachet, J.C.; Idarraga-Trujillo, I.; Le Flem, M.; Le Saux, M.; Vandenberghe, V.; Urvoy, S.; Rouesne, E.; Guilbert, T.; Toffolon-Masclet, C.; Tupin, M.; et al. Early studies on Cr-coated zircaloy-4 as enhanced accident tolerant nuclear fuel claddings for light water reactor. J. Nucl. Mater. 2019, 517, 268-285. [CrossRef]

8. Krejcí, J.; Kabatova, J.; Manoch, F.; Kocí, J.; Cvrcek, L.; Malek, J.; Krum, S.; Sutta, P.; Bublíkova, P.; Halodova, P.; et al. Development and testing of multicomponent fuel cladding with enhanced accidental performance. Nucl. Eng. Tech. 2020, 52, 597-609. [CrossRef]

9. Brachet, J.C.; Rouesne, E.; Guilbert, T.; Ribis, J.; Le Saux, M.; Nony, G.; Palancher, H.; David, A.; Bischoff, J.; Augereau, J.; et al. High temperature steam oxidation of chromium-coated zirconium-based alloys: Kinetics and process. Corros. Sci. 2020, 167, 108537. [CrossRef]

10. Yang, J.; Stegmaier, U.; Tang, C.; Steinbruck, M.; Grobe, M.; Wang, S.; Seifert, H.J. High temperature Cr-Zr interaction of two types of Cr-coated Zr alloys in inert gas environment. J. Nucl. Mater. 2021, 547, 152806. [CrossRef] 
11. Mokrushin, A.A. Results of corrosion and thermomechanical tests of ATF-cladding samples. In Proceedings of the 25th International QUENCH Workshop, Karlsruhe Institute of Technology, Karlsruhe, Germany, 22-24 October 2019.

12. Vandegrift, J.; Pargac, C.J.; Coryell, B.; Butt, D.P.; Jaques, B.J. Oxidation behavior of welded Zry-3, Zry-4, and Zr-1Nb tubes. Nucl. Mater. Energy 2019, 21, 100714. [CrossRef]

13. Slobodyan, M.S.; Kudiiarov, V.N.; Lider, A.M. Effect of energy parameters of pulsed laser welding of Zr- $1 \% \mathrm{Nb}$ alloy on metal contamination with gases and properties of welds. J. Mater. Processl Technol. 2019, 45, 472-490. [CrossRef]

14. Slobodyan, M.S.; Pavlov, S.K.; Remnev, G.E. Corrosion and high-temperature steam oxidation of E110 alloy and its laser welds after ion irradiation. Corros. Sci. 2019, 152, 60-74. [CrossRef]

15. Sakamiti, G.P.; Mota de Siqueira, R.H.; Carvalho, S.M.; Meireles, J.B.; Fernandes de Lima, M.S. Weldability of a zirconium alloy comparing resistance and pulsed laser methods. Nucl. Mat. Energy 2019, 20, 100693. [CrossRef]

16. Reitz, W.; Rawers, J. Effect of laser surface melted zirconium alloys on microstructure and corrosion resistance. J. Mater. Sci. 1992, 27, 2437-2443. [CrossRef]

17. Cai, C.; Li, L.; Tao, W. Weld Bead Size, Microstructure and corrosion behavior of zirconium alloys joints welded by pulsed laser spot welding. J. Mater. Eng. Perform. 2016, 25, 3783-3792. [CrossRef]

18. Cai, C.; Li, L.; Peng, G. Comparative study of oxides formed on fusion zone and base metal of laser welded $\mathrm{Zr}-1.0 \mathrm{Sn}-1.0 \mathrm{Nb}-0.1 \mathrm{Fe}$ alloy. J. Mater. Eng. Perform. 2019, 28, 1161-1172. [CrossRef]

19. Huang, K.-Y.; Tsai, C.-H. The effect of heat treatment on the microstructure and the corrosion resistance of Zircaloy-4 in $450{ }^{\circ} \mathrm{C}$ steam. J. Nucl. Mater. 1985, 136, 16-29. [CrossRef]

20. Goncharov, G.B.; Grabin, V.F.; Korol, A.M.; Adeeva, L.I. Structure and properties of welded joints in laser and arc welding Zr-2.5\% $\mathrm{Nb}$ alloy. J. Weld. Inter. 2009, 7, 798-801. [CrossRef]

21. Semenov, A.N.; Plyshevskii, M.I.; Melyukov, V.V. Properties of welded joints from alloy Zr- $2.5 \% \mathrm{Nb}$ after electron-beam local thermocycling. Met. Sci. Heat. Treat. 2014, 55, 670-674. [CrossRef]

22. Wan, Q.; Baib, X.; Zhanga, X. Impact of high dose krypton ion irradiation on corrosion behavior of laser beam welded zircaloy-4. Mater Res. Bull. 2006, 41, 387-395. [CrossRef]

23. Semenov, A.N.; Plyshevskii, M.I.; Gordo, V.P.; Rassoshkina, N.S.; Melyukov, V.V.; Korepanov, A.G. Optimization of the heating source in electron beam welding of zirconium pipes. J. Weld. Inter. 2013, 27, 300-303. [CrossRef]

24. Gnedenkov, A.S.; Sinebryukhov, S.L.; Mashtalyar, D.V.; Vyaliy, I.E.; Egorkin, V.S.; Gnedenkov, S.V. Corrosion of the welded aluminium alloy in $0.5 \mathrm{M} \mathrm{NaCl}$ solution. Part 2: Coating protection. Materials 2018, 11, 2177. [CrossRef]

25. Prasad Rao, K.; Janaki Ram, G.D.; Stucker, B.E. Improvement in corrosion resistance of friction stir welded aluminum alloys with micro arc oxidation coatings. Scr. Mater. 2008, 58, 998-1001. [CrossRef]

26. Aliasghari, S.; Rogov, A.; Skeldon, P.; Zhou, X.; Yerokhin, A.; Aliabadi, A.; Ghorbani, M. Plasma electrolytic oxidation and corrosion protection of friction stir welded AZ31B magnesium alloy-titanium joints. Surf. Coat. Technol. 2020, $393,125838$. [CrossRef]

27. Sidelev, D.V.; Kashkarov, E.B.; Syrtanov, M.S.; Krivobokov, V.P. Nickel-chromium (Ni-Cr) coatings deposited by magnetron sputtering for accident tolerant nuclear fuel claddings. Surf. Coat. Technol. 2019, 369, 69-78. [CrossRef]

28. Kashkarov, E.; Sidelev, D.; Syrtanov, M.; Tang, C.; Steinbrück, M. Oxidation kinetics of Cr-coated zirconium alloy: Effect of coating thickness and microstructure. Corros. Sci. 2020, 175, 108883. [CrossRef]

29. Zhang, B.; Li, X.; Wang, T.; Wang, X. Microstructure and corrosion behavior of Zr-702 joined by electron beam welding. Vacuum 2015, 121, 159-165. [CrossRef]

30. Steinbrueck, M.; Silva, F.O.; Grosse, M. Oxidation of Zircaloy-4 in steam-nitrogen mixtures at $600-1200{ }^{\circ} \mathrm{C}$. J. Nucl. Mater. 2017, 490, 226-237. [CrossRef]

31. Duriez, C.; Dupont, T.; Schmet, B.; Enoch, F. Zircaloy-4 and M5 high temperature oxidation and nitriding in air. J. Nucl. Mater. 2008, 380, 30-45. [CrossRef]

32. Xiao, W.; Chen, H.; Liu, X.; Tang, D.; Deng, X.; Zou, S.; Ren, Y.; Zhou, X.; Lei, M. Thermal shock resistance of TiN-, Cr-, and TiN/Cr-coated zirconium alloy. J. Nucl. Mat. 2019, 526, 151777. [CrossRef]

33. Chen, Q.; Xiang, Y.; Li, Z.; He, H.; Zhong, Y.; Zhu, C.; Liu, N.; Yang, Y.; Liao, J.; Chang, H.; et al. Microstructure evolution and adhesion properties of thick Cr coatings under different thermal shock temperatures. Surf. Coat. Technol. 2021, 417, 127224. [CrossRef]

34. Yang, H.L.; Matsukawa, Y.; Kano, S.; Duan, Z.G.; Murakami, K.; Abe, H. Investigation on microstructural evolution and hardening mechanism in dilute Zr-Nb binary alloys. J. Nucl. Mater. 2016, 481, 117-124. [CrossRef]

35. Kearns, J. The Use of Microhardness in the Determination of the Diffusivity of Oxygen in Alpha Zirconium; USDOC Office of Technical Services: Washington DC, USA, 1962.

36. Kashkarov, E.B.; Sidelev, D.V.; Rombaeva, M.; Syrtanov, M.S.; Bleykher, G.A. Chromium coatings deposited by cooled and hot target magnetron sputtering for accident tolerant nuclear fuel claddings. Surf. Coat. Technol. 2020, 389, 125618. [CrossRef]

37. Yeom, H.; Maier, B.; Johnson, G.; Dabney, T.; Lenling, M.; Sridharan, K. High temperature oxidation and microstructural evolution of cold spray chromium coatings on Zircaloy-4 in steam environments. J. Nucl. Mater. 2019, 526, 151737. [CrossRef]

38. Krejčí, J.; Ševeček, M.; Kabátová, J.; Manoch, F.; Kočí, J.; Cvrček, L.; Málek, J.; Krum, S.; Šutta, P.; Bublíková, P. Experimental behavior of chromium-based coatings. In Proceedings of the TopFuel 2018, Prague, Czech Republic, 30 September-4 October 2018; Available online: https:/ / www.researchgate.net/publication/328066345 (accessed on 8 May 2021). 
39. Kashkarov, E.; Afornu, B.; Sidelev, D.; Krinitcyn, M.; Gouws, V.; Lider, A. Recent advances in protective coatings for accident tolerant Zr-based fuel claddings. Coatings 2021, 11, 557. [CrossRef]

40. Michau, A.; Ougier, M.; Maskrot, H.; Brachet, J.-C.; Guilbert, T.; Palancher, H.; Bischoff, J.; Pouillier, E. Interlayers for Cr-coated nuclear fuel claddings: Preliminary study of Mo. Proceedings of NuMat 2020, Ghent, Belgium, 26-29 October 2020. [CrossRef]

41. Kalin, B.A.; Volkov, N.V.; Valikov, R.A.; Yashin, A.S. Effect of ion polishing on corrosion resistance of the cladding of fuel elements from E110 alloy in the steam water environment. Inorg. Mat. Appl. Res. 2017, 8, 364-369. [CrossRef] 